\title{
Reliugisitas Pada Waria Usia Muda
}

\author{
Rahmawati, Hadariansyah, Imadduddin \\ Universitas Islam Negeri (UIN) Antasari Banjarmasin
}

\begin{abstract}
Regardless of identity, transvestites are also human beings who must have the character to be pious. A human being with faith can be seen from how obedient he is to God or also called religiosity. Transsexual life in Banjarmasin is not very visible in the community, but in its community religious activities themselves continue to be carried out. This type of research is field research using a qualitative approach and case studies because the phenomenon of adolescent transsexual religiosity is unique to study. Data collection techniques used were the scale of religiosity, semi-structured interviews, and non-participant observation with subjects totaling two people with characteristics of transsexuals who were 18-21 years old, Muslim, were members of the IWB community and Paris Barantai, and lived in the Banjarmasin area. Both subjects have a high level of religiosity. It can also be seen that there are five dimensions of religiosity in transvestites, where both have a size of faith in a strong pillar of hope, an aspect of worship in doing fewer religious duties, a relatively good spiritual dimension, quite a proportion of religious knowledge because they at least know the basics religion, lack of practice in relations with the community and relationships with God, and the factors that influence their religiosity are the main factors, namely social influence and need elements as supporting factors.
\end{abstract}

Keyword: Transgender; Teenage; Religiosity

\begin{abstract}
Abstrak
Terlepas dari identitas, waria juga manusia yang harus memiliki sifat untuk menjadi saleh. Seorang manusia dengan iman dapat dilihat dari seberapa taat dia kepada Tuhan atau juga disebut religiositas. Kehidupan transseksual di Banjarmasin tidak terlalu terlihat di masyarakat, tetapi dalam komunitasnya kegiatan keagamaan sendiri terus dilakukan. Jenis penelitian ini adalah penelitian lapangan dengan menggunakan pendekatan kualitatif dan studi kasus, karena fenomena religiusitas transseksual remaja adalah unik untuk dipelajari. Teknik pengumpulan data yang digunakan adalah skala religiusitas, wawancara semi-terstruktur dan observasi non-partisipan dengan subyek yang berjumlah dua orang dengan karakteristik waria yang remaja berusia 18-21 tahun, beragama Islam, adalah anggota komunitas IWB dan Paris Barantai dan hidup di daerah Banjarmasin. Kedua subjek memiliki tingkat religiusitas yang tinggi. Dapat juga dilihat bahwa ada lima dimensi religiusitas dalam waria, di mana keduanya memiliki dimensi iman dalam pilar iman yang kuat, dimensi ibadah dalam hal melakukan lebih
\end{abstract}


sedikit tugas keagamaan, dimensi agama yang cukup baik, cukup dimensi pengetahuan agama karena mereka setidaknya mengetahui dasar-dasar agama, kurangnya praktik dalam hubungan dengan masyarakat dan hubungan dengan Tuhan, dan faktor-faktor yang mempengaruhi religiuistas mereka adalah faktor utama, yaitu pengaruh sosial dan faktor kebutuhan sebagai pendukung faktor-faktor.

Kata Kunci : Waria; Remaja; Reliugisitas

Bagi masyarakat, waria adalah seseorang yang dianggap aneh karena berperilaku menyimpang baik dari fisiknya, sosialnya, seksualnya, psikologisnya maupun norma (aturan). Bahkan tidak jarang keluarganya sendiri berfikir bahwa memiliki keluarga yang beridentitas waria adalah suatu aib bagi keluarga mereka. Waria juga tidak terlepas dari image kehidupan hitam seperti terjerumusnya pada dunia pelacuran, pemabuk, pengidap obat terlarang dan halhal yang menurut agama, aturan serta nilai kaidah Islam yang salah.

Stigma dan diskriminasi tersebut diperkuat lagi dengan ajaran agama-agama di dunia yang menyatakan bahwa waria adalah perbuatan dosa, sehingga hukum menjadi waria haram. Salah satunya Islam, dalam surat al-A"eraf ayat 81 dinyatakan, yang artinya "Sesungguhnya kamu mendatangi laki-laki untuk melepaskan nafsumu (kepada mereka), bukan kepada wanita, maka kamu ini adalah kaum yang melampaui batas"(Sudarman \& Hakim, 2015)

Munculnya segala stigma negatif tersebut di tengah-tengah kehidupan masyarakat umum kepada waria, tidak dapat mengkesampingkan bahwa kenyataannya waria juga adalah manusia, yang mana agama itu hadir tidak bisa direncanakan yang tetap melekat pada dirinya. Kehadiran Tuhan dalam diri manusia tidak dapat dipungkiri, inilah yang disebut dengan fitrah uluhiyah (fitrah ketuhanan) (Safri, 2014a).

Manusia yang berketuhanan dapat dilihat dari seberapa taatnya ia kepada Tuhan atau juga disebut dengan religiusitas. Religiusitas menurut Kamus Besar Bahasa Indonesia (KBBI) berarti taat pada agama, sehingga dapat dikatakan, bahwa religiusitas adalah ketaatan seorang individu terhadap perintah agama yang diyakininya (Husaini, 2016).

Menurut Khalis (2008), Konstruksi sosial, politik, budaya, dan agama yang diproduksi dan direproduksi secara terus menerus dalam masyarakat yang menafikan waria dirasakan waria sebagai himpitan yang akhirnya mendorong waria mengedap dan menyembunyikan identitas dirinya. Perasaan nyaman sebagai waria, dan perasaan berdosa dalam masyarakat akhirnya membuat waria membangun sistem nilai dan ruang sosial budaya tersendiri sebagai kelompok marginal dan eksklusif. Marginal dan eksklusifitas ini berpotensi membangun sebuah model penghayatan dan praktek keagamaan khas waria (Sudarman \& Hakim, 2015).

Kehidupan religiusitas waria di Banjarmasin tidak begitu terlihat di tengah masyarakat, namun di dalam komunitasnya sendiri kegiatan keagamaan sangat sering dilakukan seperti membaca surah Yasin, selamatan, haulan ataupun mengundang penceramah. Pakaian yang mereka kenakan beragam, ada sebagian yang memakai pakaian muslim laki-laki dan ada juga yang memakai pakaian muslim perempuan. Peminat pengajian yang hadir didominasi oleh waria dewasa sampai lanjut usia, ada juga beberapa waria remaja yang berminat hadir dalam pengajian tersebut, namun tidak sebanyak waria dewasa. 
Berdasarkan wawancara awal dan observasi peneliti bahwa waria remaja sangat minim dan tidak nampak terlihat dalam mengerjakan ibadah seperti shalat, membaca Al- Qur'an, mengikuti pengajian (ceramah). Waria remaja menganggap keagamaan sebagai sesuatu hal yang sangat membosankan untuk mereka ikuti. Waria remaja akan mengikuti kegiatan keagamaan apabila mereka memiliki teman yang sebaya yang hadir.

Istilah religiusitas berasal dari bahasa inggris "religion" yang berarti agama, kemudian menjadi kata sifat "religious" yang berarti keberagamaan atau kesalehan (Rizky Setiawan, 2014). Glock dan Stark (1966) mendefinisikan agama adalah sistem simbol, sistem keyakinan, sistem perilaku yang terlembagakan yang semuanya itu berpusat pada persoalan yang dihayati agar sebagai sesuatu yang paling maknawi (Ancok \& Nashori, 2008). Menurut C.Y. Glock dan R. Strack (1975) ada lima dimensi yang terdapat dari religiusitas (Ghufron \& Risnawita, 2010), yaitu: Dimensi keyakinan (the ideological dimension) yaitu sejauhmana seseorang menerima hal-hal yang dogmatik dalam agama mereka, Dimensi peribadatan atau praktik agama (the ritualistic dimension) yaitu tingkatan sejauhmana seseorang mengerjakan kewajiban ibadah dalam agama mereka, Dimensi penghayatan (the experiencial dimension) yaitu perasaan yang pernah dialami dan dirasakan seperti merasa dekat dengan Tuhan. , Dimensi pengetahuan agama (the knowlegde dimension) yaitu menggambarkan sejauhmana seseorang mengetahui tentang ajaran agamanya., Dimensi pengamalan (the consequential dimension) yaitu tindakan sejauhmana prilaku seseorang konsekuen atau selaras dengan ajaran dan nilai-nilai agamanya atau sejauhmana ajaran agama mempengaruhi perilaku seseorang dalam kehidupan sosialnya.

Sedangkan Waria (wanita-pria) adalah laki-laki yang lebih suka berperan sebagai perempuan dalam kehidupannya sehari-hari (Sudarman \& Hakim, 2015). Mulai dari memakai pakaian perempuan, barang perempuan (tas, sepatu, aksesoris dll), berbicara halus seperti perempuan, cara berjalan menyerupai perempuan serta memiliki orientasi sexual perempuan. Bahkan ada yang telah melakukan operasi untuk merubah penampilan fisik agar sangat terlihat seperti perempuan seutuhnya.

Secara fisik, waria sebenarnya adalah pria, namun pria (waria) ini mengidentifikasikan dirinya menjadi seorang wanita dalam tingkah laku keseharian. Seperti dalam penampilan atau dandanan, mereka mengenakan pakaian dan aksesoris seperti wanita. Demikian pula dalam perilaku sehari-hari, mereka merasa dirinya sebagai seorang yang memiliki sifat wanita.

Berdasarkan dari paparan latar belakang maka peneliti tertarik untuk meneliti tentang religiusitas pada waria berusia remaja di Kota Banjarmasin dengan berfokus kepada gambaran reliugisitas pada waria berusia remaja di Kota Banjarmasin dan juga faktor-faktor yang mempengaruhi reliugisitas pada waria remaja di Kota Banjarmasin

\section{Metode}

Jenis Penelitian ini adalah penelitian lapangan (field research) yaitu penelitian yang langsung dilakukan dilapangan untuk memperoleh data-data yang diperlukan berkenaan dengan religiusitas pada waria berusia remaja di Kota Banjarmasin. Penelitian ini menggunakan pendekatan studi kasus deskriptif kualitatif, yaitu penggalian data lapangan yang dilakukan secara mendalam, luas dan menyeluruh. Penelitian ini berlokasi di Ikatan 
Waria Banjarmasin dan Paris Barantai yang berada di Kota Banjarmasin Provinsi Kalimantan Selatan. Dalam penelitian ini yang dijadikan subjek adalah 4 orang waria yang terdiri dari 2 orang anggota waria Ikatan Waria Banjarmasin dan 2orang anggota waria Paris Barantai yang berusia 18 - 21 tahun, beragama Islam serta bertempat tinggal di daerah Banjarmasin. Objek penelitian ini ialah religiusitas dan memfokuskan pada dimensi religiusitas pada waria usia remaja di Kota Banjarmasin menurut teori C.Y. Glock dan R. Strack yaitu: dimensi keyakinan (the ideological dimension), dimensi peribadatan atau praktik agama (the ritualistic dimension), dimensi penghayatan (the experiencial dimension), dimensi pengetahuan agama (the knowlegde dimension) dan dimensi pengamalan (the consequential dimension).

Data dalam penelitian ini dibagi menjadi dua, yaitu data primer berupa data-data hasil observasi dan wawancara mendalam dengan subjek dan informan mengenaireligiusitas pada diri wariayang beragama Islam berusia 18 - 21 tahun di daerah Kota Banjarmasin dan data sekunder berupa data yang mendukung dalam penelitian dapat diperoleh dari berbagai sumber tulisan seperti buku-buku, penelitian skripsi, penelitian jurnal, penelitian makalah, literatur internet atau dari literatur lain yang dapat dijadikan referensi bagi penelitian ini.

Sumber data adalah subjek waria itu sendiri yang beragama Islam, berusia 18-21 tahun dan tinggal di Kota Banjarmasin dan juga informan yaitu orang yang memberikan informasi berupa data tambahan serta penguata yaitu keluarga dan tetangga subjek penelitian dan pihak lainnya yang dapat memberikan informasi terkait dengan penelitian ini. Pengumpulan data ialah langkah yang sangat penting dalam penelitian kualitatif, sebab peneliti harus pandai dalam mengelola waktu yang dimiliki, menampilkan diri, dan bergaul di tengah masyarakat yang dijadikan subjek penelitiannya. Teknik pengumpulan data yang dilakukan dalam penelitian ini ialah skala, wawancara dan observasi. Skala reliugisitas yang dipakai pada penelitian ini diadaptasi dari penelitian tingkat religiusitas yang disusun oleh Satriani dengan Jumalh aitem skala reliugisitas sebanyak 42 aitem dengan koefisien korelasi berkisar antara 0,303-0,655 dan koefisien reliabilitas sebesar 0,920 (Satriani, 2011). Jenis wawancara yang digunakan dalam penelitian ini yaitu wawancara semi terstruktur yang bertujuan untuk menemukan permasalahan secara lebih terbuka. Data yang diperoleh dari hasil wawancara berupa identitas subjek, penyebab terbentuknya sikap waria pada diri subjek dan hal yang dapat mendorong atau menghambat dalam proses religiusitas subjek dari berbagai dimensidimensi teori C.Y. Glock dan R. Strack. Dalam penelitian ini Peneliti menggunakan jenis observasi nonpartisipan yaitu peneliti tidak terlibat atau mengambil bagian dalam aktivitas yang dilakukan subjek (Fahmi \& Kusdiyati, 2015). atau peneliti tidak terlibat langsung dalam kehidupan sehari-hari subjek. Metode ini digunakan untuk mengamati perilaku waria antara lain adalah penampilan, gaya bicara, gestur, lingkungan tempat tinggal dan prilaku subjek saat berhubungan dengan sesama komunitas warianya.

Tahapan dalam pengolahan data sebelum melakukan analisis adalah sebagai berikut (Rahmadi, 2011): melakukan pencatatan terhadap semua data yang terkumpul baik dari skala, wawancara dan observasi yang relevan dengan penelitian, mereduksi data sehingga tidak ada data yang overlapping, mengelompokkan data berdasarkan tema, mengidentifikasi data dengan cara mengecek ulang kelengkapan transkip wawancara dan catatan lapangan dan menggunakan data yang valid dan relevan. Metode analisis dalam penelitian proses penyederhanaan, mencari 
dan menyusun secara sistematis dari sejumlah data yang telah diperoleh dari sumber lapangan ataupun literatur buku. Sehingga dapat mudah dipahami oleh diri sendiri maupun orang lain.

\section{Identitas Subjek Penelitian}

\section{Hasil}

Subjek pada penelitian ini, awalnya meneliti subjek yang berjumlah empat orang waria berusia remaja. Peneliti telah mendapatkan nama ke empat anggota waria remaja dari masingmasing komunitas tersebut, yang terdiri dari dua anggota Ikatan Waria Banjarmasin yaitu V dan M sedangkan dua anggota Paris Barantai yaitu RS dan S. Namun dalam proses selanjutnya, dua subjek dikeluarkan dari penelitian karena tidak memenuhi kirteria yang sudah ditentukan oleh peneliti. Akhirnya penelitian ini dilakukan di Banjarmasin Provinsi Kalimantan Selatan dengan jumlah subjek 2 orang waria berusia remaja. Adapun yang menjadi karakteristik subjek dalam penelitian ini berusia remaja yaitu 18 - 21 tahun, beragama Islam dan berdomisili di daerah Banjarmasin, serta subjek penelitian terdiri dari 1 orang anggota waria Ikatan Waria Banjarmasin yaitu subjek V dan 1 orang anggota waria Paris Barantai yaitu subjek R.

Selengkapnya identitas subjek penelitian dapat dipaparkan dalam tabel. 1 berikut ini:

Table.1. Identitas subjek

\begin{tabular}{cccccc}
\hline $\begin{array}{c}\text { Subjek } \\
\text { (Inisial) }\end{array}$ & Usia & $\begin{array}{c}\text { Pendidikan } \\
\text { Terakhir }\end{array}$ & Alamat & Pekerjaan & Agama \\
\hline $\mathrm{V}$ & 21 & SD & Jalan A.Yani, Km 4,5 & - & Islam \\
$\mathrm{R}$ & 19 & MTS & Jalan Veteran & $\begin{array}{c}\text { Penyanyi } \\
\text { Dangdut }\end{array}$ & Islam \\
\hline
\end{tabular}

Reliugisitas pada Waria Berusia Remaja

Berdasarkan kategorisasi variabel tingkat religiusitas maka kategori tingkat religiusitas kedua subjek yaitu:

Tabel. 2. Tingkat Reliugisitas

\begin{tabular}{lll}
\hline Subjek & Nilai & Kategori \\
\hline Subjek V & 132 & Tinggi \\
Subjek R & 130 & Tinggi \\
\hline
\end{tabular}


Gambaran reliugistas pada kedua subjek dapat dilihat dalam tabel .3 berikut:

Table.3 Gambaran Reliugisitas

\begin{tabular}{|c|c|c|c|}
\hline $\mathrm{No}$ & $\begin{array}{l}\text { Gambaran } \\
\text { religiusitas }\end{array}$ & Subjek V & Subjek R \\
\hline 1. & $\begin{array}{l}\text { Dimensi } \\
\text { keyakinan }\end{array}$ & $\begin{array}{l}\text { Keyakinan terhadap rukun } \\
\text { Iman sangat kuat. (sangat } \\
\text { kuat) }\end{array}$ & $\begin{array}{l}\text { Keyakinan terhadap rukun Iman } \\
\text { sangat kuat. } \\
\text { (sangat kuat) }\end{array}$ \\
\hline 2. & $\begin{array}{l}\text { Dimensi } \\
\text { peribadatan } \\
\text { atau praktik } \\
\text { agama }\end{array}$ & $\begin{array}{l}\text { Jarang menjalankan ibadah } \\
\text { sholat wajib lima waktu, sholat } \\
\text { Jumat dan membaca Al- } \\
\text { Quran. (kurang) }\end{array}$ & $\begin{array}{l}\text { Jarang menjalankan ibadah } \\
\text { sholat wajib lima waktu, sholat } \\
\text { Jumat dan membaca Al- } \\
\text { Quran.(kurang) }\end{array}$ \\
\hline 3. & $\begin{array}{l}\text { Dimensi } \\
\text { penghayatan }\end{array}$ & $\begin{array}{l}\text { Setelah melakukan ibadah } \\
\text { sholat merasakan ketenangan, } \\
\text { merasakan ketakutan terhadap } \\
\text { dosa, merasa bersyukur } \\
\text { kepada Allah SWT. (cukup } \\
\text { bagus) }\end{array}$ & $\begin{array}{l}\text { Setelah melakukan ibadah sholat } \\
\text { merasakan ketenangan, di saat } \\
\text { sholat merasakan sangat dekat } \\
\text { dengan Allah SWT, merasakan } \\
\text { ketakutan terhadap dosa, merasa } \\
\text { bersyukur kepada Allah SWT. } \\
\text { (sangat bagus) }\end{array}$ \\
\hline 4. & $\begin{array}{l}\text { Dimensi } \\
\text { pengetahuan } \\
\text { agama }\end{array}$ & $\begin{array}{l}\text { Mengetahui rukun Islam, } \\
\text { Akhlak, isi kandungan Al- } \\
\text { Quran serta sejarah nabi dan } \\
\text { rasul } \\
\text { (kurang bagus) }\end{array}$ & $\begin{array}{l}\text { Mengetahui rukun Islam, rukun } \\
\text { iman, Akhlak, Fiqih, isi } \\
\text { kandungan Al-Quran, tata cara } \\
\text { sholat, sering kepengajian,serta } \\
\text { cerita nabi-nabi (cukup bagus) }\end{array}$ \\
\hline 5. & $\begin{array}{l}\text { Dimensi } \\
\text { pengamalan }\end{array}$ & $\begin{array}{l}\text { Suka menolong, menghormati } \\
\text { orang lain, tidak suka } \\
\text { mengatakan kata hinaan, suka } \\
\text { menyapa tetangga, memiliki } \\
\text { hubungan sesama jenis, } \\
\text { pernah merasakan minuman } \\
\text { keras, pemarah, tidak bisa } \\
\text { bergaul dengan tetangga. } \\
\text { (kurang bagus) }\end{array}$ & $\begin{array}{l}\text { Suka menolong, suka menyapa } \\
\text { tetangga, suka bersedekah, } \\
\text { memiliki hubungan sesama jenis, } \\
\text { sering meminum minuman } \\
\text { keras, tidak bisa bergaul dengan } \\
\text { tetangga, suka berkata kasar } \\
\text { (kurang bagus) }\end{array}$ \\
\hline
\end{tabular}


Faktor-Faktor yang Mempengaruhi Reliugisitas pada Waria berusia Remaja

Faktor-faktor yang mempengaruhi reliugistas pada kedua subjek adalah sebagai berikut:

\begin{tabular}{|c|c|c|c|}
\hline No. & $\begin{array}{l}\text { Faktor yang } \\
\text { mempengar } \\
\text { uhi } \\
\text { religiusitas }\end{array}$ & Subjek V & Subjek R \\
\hline 1. & $\begin{array}{l}\text { Faktor } \\
\text { pengaruh } \\
\text { sosial }\end{array}$ & $\begin{array}{l}\text { Pendidikan agama dari } \\
\text { sekolah Mts, dari } \\
\text { orangtua, dari TPA, } \\
\text { sikap orang-orang } \\
\text { sekitar terhadap dirinya } \\
\text { saat melakukan ibadah } \\
\text { di mesjid, rasa beragama } \\
\text { yang kurang dan } \\
\text { keyakinan yang kuat } \\
\text { terhadap ajaran agama }\end{array}$ & $\begin{array}{l}\text { Pendidikan agama dari sekolah } \\
\text { Mts, tantenya dan pengajian rutin } \\
\text { yang dihadirinya, sikap orang- } \\
\text { orang sekitar terhadap dirinya saat } \\
\text { melakukan ibadah di mesjid, rasa } \\
\text { beragama yang kurang, keyakinan } \\
\text { yang kuat terhadap ajaran agama } \\
\text { serta perbedaan budaya yang } \\
\text { mempengaruhi ibadah di } \\
\text { lingkungan tempat tinggalnya. }\end{array}$ \\
\hline 2. & Kebutuhan & $\begin{array}{l}\text { Menginginkan rasa } \\
\text { keamanan dan } \\
\text { keselamatan di dunia } \\
\text { dan di akhirat, } \\
\text { menginginkan rasa aman } \\
\text { serta ketenangan tanpa } \\
\text { rasa cemas dan } \\
\text { ketakutan. }\end{array}$ & $\begin{array}{l}\text { Menginginkan rasa keamanan dan } \\
\text { keselamatan di dunia dan di } \\
\text { akhirat, menginginkan rasa aman } \\
\text { serta ketenangan tanpa rasa cemas } \\
\text { dan ketakutan. }\end{array}$ \\
\hline
\end{tabular}

\section{Pembahasan}

Gambaran reliugistas pada waria berusia remaja

Dalam pandangan Psikologis, waria di nyatakan mengalami gangguan identitas gender dimana seseorang merasa bahwa dirinya adalah seorang pria atau wanita. Orang dengan gangguan ini mereka merasa bahwa anatomi gender mereka merupakan sumber distres yang terus ada dan intensif, bahkan dapat mencoba untuk mengubah organ seks mereka sehingga menyerupai lawan jenis (Medya \& C Kristiaji, 2005). Menurut Carroll (Ruhghea, Mirza, \& Rachmatan, 2014), individu dengan gangguan identitas gender umumnya sudah mulai merasakan indikasi gangguan terebut sejak kecil, dimana ia merasa dan meyakini bahwa dirinya adalah jenis kelamin yang berbeda dengan jenis kelaminnya saat ini, dan perasaan ini terus berlanjut hingga masa dewasa. Terdapat tiga faktor utama yang dapat menyebabkan terjadinya perubahan identitas seoranglelaki menjadi waria, yaitu (1)pola pendidikan, 
perlakuan dan pola asuh orangtua; (2) kecenderunganpsikis dan nyamanmenjadiwaria; dan(3) kekerasan seksual (sodomi) yang pernah diterima (Faidah \& Abdullah, 2014).

Menurut Dewi Muth'iah (Dewi Muthi'ah, 2007) terbentuknya waria dalam diri seseorang disebabkan adanya faktor-faktor, yaitu faktor psikologis, faktor biologis, dan faktor sosiologis. Berdasarkan faktor-faktor dan pernyataan Carroll tersebut dan selaras dengan hasil yang telah diperoleh peneliti, dapat diketahui bahwa subjek $\mathrm{V}$ dan subjek $\mathrm{R}$ mengalami gangguan identitas gender, dan faktor yang menyebabkan subjek $\mathrm{V}$ dan subjek $\mathrm{R}$ menjadi waria yaitu faktor psikologis, dimana $\mathrm{V}$ mengaku lebih nyaman ketika dirinya menjadi perempuan sejak usia 3 tahun, sedangkan R sejak usia 6 tahun, baik R maupun V sama-sama memiliki dorongan atau motivasi diri sendiri untuk berperilaku dan berpakaian perempuan, serta $\mathrm{V}$ dan $\mathrm{R}$ lebih nyaman berteman dengan wanita sejak mereka kecil hingga memasuki masa remaja. $\mathrm{V}$ juga menambahkan bahwa keluarga menjadi bagian yang sangat penting dalam awal mula proses dirinya menjadi seorang waria, dimana $\mathrm{V}$ pada masa kanak-kanak selalu dipakaikan pakaian dan aksesoris wanita, selain itu ketika V dipakaikan pakaian dan aksesoris wanita dia juga diperlakukan seperti seorang wanita oleh Ibu dan saudara-saudara perempuannya, yang tanpa disadari hal itu mengakibatkan dirinya menjadi seorang waria.

Bagi masyarakat, waria adalah seseorang yang dianggap aneh dan berperilaku menyimpang baik dari fisiknya, sosialnya, seksualnya, psikologisnya maupun norma (aturan). Waria juga tidak terlepas dari image kehidupan hitam seperti terjerumusnya pada dunia pelacuran, pemabuk, pengidap obat terlarang dan hal-hal yang menurut agama, aturan serta nilai kaidah Islam yang salah. Munculnya segala stigma negatif tersebut di tengah-tengah kehidupan masyarakat umum kepada waria, tidak dapat mengkesampingkan bahwa kenyataannya waria juga adalah manusia, yang mana agama itu hadir tidak bisa direncanakan yang tetap melekat pada diriya. Kehadiran Tuhan dalam diri manusia tidak bisa dipungkiri, inilah yang disebut dengan fitrah uluhiyah (fitrah ketuhanan) (Safri, 2014b). Manusia yang berketuhanan dapat dilihat dari seberapa taatnya ia kepada Tuhan atau juga disebut dengan religiusitas. Religiusitas menurut Kamus Besar Bahasa Indonesia (KBBI) berarti taat pada agama, sehingga dapat dikatakan, bahwa religiusitas adalah ketaatan seorang individu terhadap perintah agama yang diyakininya (Husaini, 2016). Menurut Abdul Muiz, waria dengan apapun atribut yang dikenakannya, baik ketika di luar peribadatan maupun di dalam, waria adalah manusia yang masih ingat akan Tuhannya (Muiz, 2015)

Schaeffer dan Mattis, berpendapat bahwa religiusitas adalah ritual individu dan praktik penyembahan tertinggi yang terorganisir yang diasosiasikan dengan kekakuan sistem dan keyakinan individual yang sangat pribadi, atau seberapa kuat individu penganut agama merasakan pengalaman beragama sehari-hari, mengalami kebermaknaan hidup dalam beragama, mengekspresikan keagamaan sebagai sebuah nilai, meyakini ajaran agamanya, memaafkan, melakukan praktik keagamaan atau ibadah secara menyendiri (Husaini, 2016).

Kehidupan religiusitas waria di Banjarmasin tidak begitu terlihat di tengah masyarakat, namun didalam organisasi atau komunitasnya sendiri kegiatan keagamaan itu ada untuk dilakukan, di Banjarmasin terdapat komunitas waria yang bernama IWB (Ikatan Waria Banjarmasin) yang diketuai oleh Susan (50 tahun) dan Paris Barantai yang diketuai oleh Lili (40 tahun). 
Dari masing-masing komunitas tersebut terdapat satu anggota waria berusia remaja yang menjadi subjek penelitian ini, yaiu subjek $\mathrm{V}$ dan subjek R. Berdasarkan hasil angket skala tingkat religiusitas yang diberikan kepada kedua subjek, dapat diketahui bahwa kedua subjek memiliki tingkat religiusitas yang tinggi.

Kedua subjek tersebut diketahui memiliki usia yang sedang memasuki masa remaja akhir (17-21 tahun), menurut Yusriana bahwa berdasarkan sifat atau perkembangannya remaja akhir memiliki masa (Yusriana, 2013) yaitu: menampakkan pengungkapan kebebasan diri, dalam mencari teman sebaya lebih selektif, memiliki citra (gambaran,keadaan,peranan) terhadap dirinya, dan dapat mewujudkan perasaan cinta.

Kedua subjek mereka memiliki keinginan untuk mengungkapan kebebasan terhadap dirinya, yang tidak ingin di atur, khususnya terhadap kehidupan beragamanya, mereka melakukan ibadah ketika mereka menginginkannya. Hasil penelitian ini juga mendukung pendapat Palaotzian bahwa keterlibatan remaja dalam beragama sering tidak konsisten yang artinya waria berusia remaja kelihatannya menjadi sangat religius, tetapi juga bisa kelihatan tidak religius, suatu saat nampak sangat intens untuk percaya dan terlibat atau melaksanakan ajaran agama, tetapi pada suat saat juga memiliki banyak kekurangan dalam hal mempercayai agama dan kurang dalam melaksanakan ajaran agamanya (Afiatin, 1998).

Subjek juga terlihat lebih selektif dalam memilih teman, karena mereka hanya berteman dengan yang dapat menerima dia ataupun memiliki kesaman segala sesuatu dengan dirinya, contohnya seperti berteman dengan sesama waria, dan hal itulah yang membuat mereka masuk ke dalam komunitas waria. Selain itu, kedua subjek juga mampu menggambarkan keadaan tentang dirinya sendiri mengenai segala perilaku yang telah dilakukan, pemikiran yang ia peroleh, ataupun perasaan yang dirasakannya mengenai berketuhanan selama proses wawancara.

Berkenaan juga tentang perkembangan masa remaja akhir, dalam bukunya Sarlito, pada proses penyesuaian diri menuju kedewasaan menurut Petro Blos (1962) mengatakan bahwa, pada masa remaja akhir menuju periode dewasa, ditandai dengan pencapaian lima hal, yaitu (Sarwono, 2012): 1) Minat yang makin mantap terhadap fungsi-fungsi intelek, 2) Egonya mencari kesempatan untuk bersatu dengan orang-orang lain dan dalam pengalamanpengalaman baru, 3) Terbentuk identitas seksual yang tidak akan berubah lagi, 4) Egosentrisme (terlalu memusatkan perhatian pada diri sendiri) diganti dengan keseimbangan antara kepentingan diri sendiri dengan orang lain, dan 5) Tumbuh dinding yang memisahkan diri pribadinya dan masyarakat umum.

Sesuai dengan masa perkembangan remaja akhir berdasarkan dari lima hal yang telah disebutkan, terdapat beberapa hal yang menunjukan bahwa mereka memasuki masa remaja akhir pada kedua subjek, yaitu dimana mereka sama-sama memiliki keinginan untuk selalu berteman dengan teman mereka, meskipun yang dilakukannya adalah hal yang tidak baik seperti rutinitas pesta peringatan ulang tahun yang diiringi dengan pesta minuman keras. Mereka juga sama-sama kurang bergaul dalam masyarakat, dimana mereka mulai memisahkan diri pribadi mereka dengan masyarakat tempat tinggal mereka. Mereka juga memiliki identitas seksual yang tidak akan berubah lagi, terlihat pada ketertarikannya terhadap sesama jenis, baik subjek $\mathrm{V}$ dan $\mathrm{R}$ sama-sama memiliki hubungan sesama jenis. 
Kedua subjek memiliki latar belakang keluarga yang berbeda, Subjek V masih memiliki keluarga yang sempurna dan mendapatkan dukungan serta kasih sayang penuh dari seluruh keluarganya, tetapi meskipun $\mathrm{V}$ mendapat kasih sayang dan dukungan terhadapnya yang beridentitaskan sebagai waria, orangtuanya tetap selalu berharap agar dirinya kembali menjadi jati dirinya yaitu sebagai seorang laki-laki, sedangkan $\mathrm{R}$ tidak merasa mendapatkan dukungan serta kasih sayang oleh keluarganya, karena Ibu $\mathrm{R}$ yang telah meninggal dunia lalu dia tinggal bersama dengan tantenya, meskipun dia tinggal bertetangga dengan ayah dan ibu tirinya, tetap saja dia merasa bahwa orangtuanya tidak memperhatikan dan tidak mendukung dia, apalagi dengan kondisinya sekarang sebagai waria.

Lingkungan tempat tinggal yang ditempati oleh kedua subjek juga berbeda, subjek $\mathrm{V}$ bertempat tinggal yang lebih religius dibandingkan lingkungan tempat tinggal $\mathrm{R}$. Tempat tinggal V lebih banyak memiliki kegiatan keagamaan yang dilakukan, seperti pengajian lakilaki dan pengajian perempuan, pengadaan grup maulid habsyi, dan lingkungan yang tidak terlihat kegiatan negatif seperti mabuk-mabukan dll. Sedangkan tempat tinggal yang di tempati subjek $\mathrm{R}$ tidak memiliki kegiatan keagamaan sama sekali, mushola yang ada hanya digunakan oleh orang-orang tertentu saja, peneliti pun saat berkunjung ke tempat tinggal $\mathrm{R}$ dan selama memasuki komplek tempat tinggalnya tersebut peneliti selalu melihat laki-laki yang bertato dan rambut berwarna, mulai dari remaja hingga orang tua, meskipun begitu tetangga - tetangga subjek $\mathrm{V}$ dan subjek $\mathrm{R}$ sangat sopan, ramah dan baik terhadap orang baru yang dikenal.

Menurut Harlock (1973), religiusitas terbagi menjadi dua unsur, yaitu unsur keyakinan terhadap ajaran agama dan unsur pelaksanaan ajaran agama (Ghufron \& Risnawita, 2010). Glock dan Stark (1966), mendifinisikan agama adalah sistem simbol, sistem keyakinan, sistem perilaku yang terlembagakan yang semuanya itu berpusat pada persoalan yang dihayati agar sebagai sesuatu yang paling maknawi (Ancok \& Nashori, 2008). C.Y. Glock dan R. Strack (1975) juga memaparkan ada beberapa dimensi dalam religiusitas, yaitu (Ghufron \& Risnawita, 2010):

I. Dimensi keyakinan (the ideological dimension) yaitu sejauhmana seseorang menerima hal-hal yang dogmatik dalam agama mereka.

2. Dimensi peribadatan atau praktikagama(the ritualistic dimension) yaitu tingkatan sejauhmana seseorang mengerjakan kewajiban ibadah dalam agama mereka.

3. Dimensi penghayatan (the experiencial dimension) yaitu perasaan yang pernah dialami dan dirasakan seperti merasa dekat dengan Tuhan.

4. Dimensi pengetahuan agama (the knowlegde dimension) yaitu menggambarkan sejauhmana seseorang mengetahui tentang ajaran agamanya.

5. Dimensi effect pengamalan (the consequential dimension) yaitu tindakan sejauhmana prilaku seseorang konsekuen atau selaras dengan ajaran dan nilai-nilai agamanya atau sejauhmana ajaran agama mempengaruhi perilaku seseorang dalam kehidupan sosialnya.

Dalam hal ini dimensi-dimensi religiusitas subjek akan digambarkan dimensi perdimensi. Pada dimensi keyakinan, yaitu sejauhmana seseorang menerima dan percaya halhal yang dogmatik dalam agama mereka (Ghufron \& Risnawita, 2010). Dimensi ini berisi pengharapan seseorang yang berpegang teguh pada pandangan teologis tertentu dan 
mengakui kebenaran doktrin-doktrin tersebut (Ancok \& Nashori, 2008). Ada tiga kategori kepercayaan (Jalaluddin Rakhmat, 2004):

I. Kepercayaan yang menjadi dasar esensial suatu agama. Contohnya dalam Islam percaya kepada Allah SWT beserta Nabi Muhammad SAW

2. Kepercayaan yang berkaitan dengan tujuan ilahi dalam penciptaan manusia.

3. Kepercayaan yang berkaitan dengan cara terbaik untuk melaksanakan tujuan ilahi tersebut.

Subjek $\mathrm{V}$ dan Subjek $\mathrm{R}$ sama-sama memiliki keyakinan yang sangat kuat terhadap rukun Iman, yaitu mereka percaya atau meyakini adanya Allah SWT, malaikat-malaikat, kitab-kitab, nabi dan rasul, kiamat serta qada dan qadar, meskipun $\mathrm{R}$ sempat meragukan keberadaan Allah SWT, dimana Hasil ini sependapat dengan Daradjat bahwa pada masa remaja mulai ada keragu-raguan terhadap kaidah-kaidah akhlak dan ketentuan-ketentuan agama, jadi mereka lebih kritis dalam berfikir (Ghufron \& Risnawita, 2010).

Walaupun mereka diberikan keadaan oleh Allah SWT sebagai waria yang tidak ada satupun yang menginginkan kondisi tersebut, mereka masih yakin terhadap rencana Allah SWT yang pasti akan selalu baik kedepannya, dan mereka mampu menikmati dan mensyukuri pemberian yang telah diberikan kepada mereka atas kondisi mereka saat ini. Mereka pun tidak menutup kemungkinan besar untuk meyakini bahwa mereka suatu saat nanti akan kembali kepada jati diri mereka masing-masing yaitu sebagai laki-laki, apabila itu semua dikehendaki Allah SWT. Mereka berdua juga sama-sama memiliki tujuan hidup yaitu membahagiakan kedua orang tua mereka dan ingin sukses dalam bekerja, dimana mereka sadar dan yakin apabila mereka berusaha menjadi lebih baik, mengerjakan sholat dan selalu berdoa mereka akan bisa mencapai tujuan hidup mereka tersebut.

Dari segi aspek peribadatan dan praktik agama, yaitu tingkatan sejauhmana seseorang mengerjakan kewajiban ibadah dalam agama mereka (Ghufron \& Risnawita, 2010). Dimensi ini mencakup perilaku pemujan, ketaatan, dan hal - hal yang dilakukan orang untuk menunjukkan komitmen terhadap agama yang dianutnya (Ancok \& Nashori, 2008). Semakin terorganisasi sebuah agama, semakin banyak aturan yang dikenakan kepada pengikutnya, aturan ini berkisar dari tata cara beribadah hingga jenis pakaian yang dipakai (Jalaluddin Rakhmat, 2004). Contohnya yaitu bagi umat Islam menunaikan shalat, zakat, puasa, haji, dll.

Kedua subjek juga sama-sama memiliki peribadatan atau praktik agama yang kurang, mereka mengerjakan rukun yang terdapat dalam rukun Islam, seperti sholat, puasa dan berzakat, namun mereka tidak melakukannya secara sempurna. Seperti sholat, mereka samasama jarang untuk melakukan sholat lima waktu, sholat jumat sekalipun dimana itu merupakan kewajiban yang dilakukannya hanya satu minggu satu kali, sebagai umat muslim khususnya laki-laki. Tata cara dan pakaian ibadah sholat yang dikerjakan subjek $\mathrm{V}$ apabila dia dirumah dia mengenakan peci, sarung dll seperti pakaian ibadah laki-laki pada umumnya, sedangkan saat bersama dengan kekasih laki-lakinya dia mengenakan pakain ibadah wanita yaitu mukena karena beralasan menghormati kekasih laki-lakinyatersebut. Berbeda halnya dengan $\mathrm{R}$ selama hidupnya dia selalu sholat menggunakan tata cara ibadah laki-laki dan mengenakan pakaian laki-laki seperti peci, sarung, ataupun gamis. Disini dapat ditarik kesimpulan bahwa ketika mereka berhubungan dengan manusia, mereka memakai pakaian 
atau menampakkan dirinya sebagai perempuan, namun ketika mereka berhubungan dengan Allah mereka memakai pakaian atau menampakkan dirinya kembali sebagai jati dirinya semula yaitu laki-laki. Dalam hal berdzikir, berdasarkan pernyataan yang peneliti peroleh melalui kedua subjek, apabila mereka melakukan sholat maka mereka berdzikir dan berdoa, namun apabila mereka tidak mengerjakan sholat maka mereka tidak berdzikir dan berdoa. Diketahui juga Subjek V jarang untuk membaca Al-Quran dikarenakan tidak memiliki waktu untuk membaca Al-Qur'an, sedangkan subjek R tidak pernah membaca Al-Qur'an dari SD hingga sekarang karena dia beralasan bahwa tidak terlalu lancar dalam membaca Al-Qur'an. Dari kedua subjek $\mathrm{V}$ dan $\mathrm{R}$, berdasarkan hasil wawancara dengan masing-masing informan, menurut mereka baik $\mathrm{V}$ maupun $\mathrm{R}$ terdapat suatu fakta bahwa, semenjak mereka masuk kedalam komunitas waria, mereka menjadi tidak pernah terlihat bergaul dengan masyarakat, tidak terlihat untuk sholat lagi di mesjid, bahkan terlalu sering berteman dengan sesama mereka yaitu waria.

Dalam dimensi penghayatan, yaitu perasaan keagamaan yang pernah dialami dan dirasakan (Ghufron \& Risnawita, 2010). Dimensi ini berkaitan dengan pengalaman keagamaan, perasaan-perasaan, persepsi-persepsi, dan sensasi-sensasi yang dialami seseorang untuk didefinisikan oleh suatu kelompok keagamaan dalam berkomunikasi kepada Tuhan (Ancok \& Nashori, 2008). Dalam agama Islam seperti perasaan yang dirasakan oleh para sufi berupa kekhusyukan yang intens dalam beribadah, merasa dekat dengan Tuhan, tentram saat berdoa, tersentuh mendengar ayat suci Al-Quran, merasa takut berbuat dosa, merasa senang doanya dikabukan.

Kedua subjek juga memiliki penghayatan yang cukup bagus, karena mereka mulai menemukan pengalaman dan penghayatan ketuhanan yang bersifat individual, hubungan mereka dengan Tuhan sudah mulai semakin mempunyai rasa kesadaran dan diimbangi dengan kegiatan keagamaan ditengah masyarakat (Ghufron \& Risnawita, 2010). Namun berdasarkan dari pengakuan-pengakuan yang dikatakan oleh subjek melalui pertanyaan yang peneliti berikan, subjek $\mathrm{R}$ memiliki penghayatan yang lebih bagus dari pada subjek $\mathrm{V}$, karena $\mathrm{R}$ sangat merasa dekat dan merasa mempasrahkan diri sepenuhnya saat melakukan sholat kepada AllahSWT. Sedangkan subjek V tidak merasakan apa-apa saat melakukan sholat, dia hanya melaksanakan atau menggugurkan kewajibannya saja. Namun keduanya mengaku hatinya sangat tenang, dan fikirannya sangat jernih ketika setelah selesai melakukan sholat, dzikir dan berdoa. Hasil wawancara tersebut sependapat dengan pernyataan Kirkpatrick, yaitu seseorang yang melakukan ibadah dapat menambah kebahagiaan dalam diri setiap individu (Khairunnisa \& Indrawati, 2017).

Subjek $\mathrm{V}$ dan subjek $\mathrm{R}$ juga sama-sama merasakan ketakutan yang sangat besar terhadap dosa yang telah dilakukannya selama hidup di dunia ini.V sangat takut terhadap azab dan kiamat yang diberikan oleh Allah SWT, sedangkan R sangat takut terhadap kematian apabila terjadi kepadanya dengan secara mendadak tanpa sempat bertaubat kepada Allah SWT. Sama halnya dengan rasa kebersyukuran yang kedua subjek rasakan, mereka sama-sama sangat bersyukur dan berterima kasih kepada Allah SWT atas segala nikmat dan rezeki yang telah diberikan kepada mereka, apalagi ketika doa mereka dikabulkan oleh Allah SWT.

Sedangkan pada dimensi pengetahuan agama, yaitu menggambarkan sejauhmana seseorang mengetahui tentang ajaran agamanya. Dimensi ini mengacu pada harapan bahwa 
orang-orang yang beragama paling tidak memiliki sejumlah minimal pengetahuan mengenai dasar-dasar keyakinan, ritual, kitab suci, dan tradisi-tradisi (Ancok \& Nashori, 2008). Contohnya seperti Ilmu Fiqih dalam Islam menghimpun informasi tentang fatwa ulama berkenaan dengan pelaksanaan ritual keagamaan (Ancok \& Nashori, 2008), memahami isi dan kandungan Al-Qur'an dll. Dari hasil yang telah peneliti peroleh, subjek V memiliki pengetahuan yang kurang dibandingkan dengan pengetahuan agama yang subjek $\mathrm{R}$ miliki, saat ditanyai peneliti tentang mengenai pengetahuan agama, $\mathrm{V}$ mengaku kurang mengetahui dan kurang mengerti tentang rukun iman, tata cara sholat, hukum Islam, dan ilmu Fiqih, namun dalam hal rukun Islam, cerita-cerita sejarah mengenai nabi dan rasul, akhlak atau perilaku serta beberapa isi kandungan Al-Qur'an diriya dapat mengetahui tentang hal itu semua. Subjek R meskipun ketika ditanya mengenai rukun Iman dan hukum Islam mengaku kurang mengetahui tentang hal tersebut, namun $\mathrm{R}$ mengetahui rukun Islam, tata cara ibadah sholat, Fiqih, Akhlak serta beberapa isi kandungan dalam Al-Qur'an.

Berdasarkan dimensi terakhir yaitu dimensi pengamalan, atau tindakan sejauhmana perilaku seseorang selaras dengan ajaran dan nilai-nilai agamanya, dimana komponen ini tidak hanya memberikan bimbingan dalam melakukan hal yang benar dari ritual-ritual atau praktik ibadah dalam agama, namun juga sejauhmana ajaran agama mempengaruhi perilaku seseorang dalam kehidupan sosialnya. Dimensi ini menunjukkan akibat ajaran agama dalam perilaku umum yang tidak secara langsung dan secara khusus ditetapkan agama dalam kesehariannya, efek agama ini boleh jadi positif atau negatif pada tingkat personal dan sosial (Jalaluddin Rakhmat, 2004). Contoh dimensi ini yaitu mendermakan harta untuk keagamaan dan sosial, menjenguk orang sakit, mempererat silaturahmi, suka menolong, berlaku jujur, bekerjasama, menegakkan keadilan, kesejahteraan orang lain, mematuhi norma-norma dll.

Subjek $\mathrm{V}$ maupun subjek $\mathrm{R}$ memiliki pengamalan yang kurang, keduanya memiliki kesamaan dan perbedaan dalam hal positif dan negatif yang telah kedua subjek tunjukandalam proses wawancara maupun pengamatan peneliti, baik terhadap diri mereka pribadi maupun sosial mereka.

Subjek V mengaku bahwa dirinya suka menolong, tidak terbiasa mengucapkan katakata hinaan terhadap orang lain dan suka menegur para tetangganya ketika sedang lewat atau bertemu, namun $\mathrm{V}$ tidak bisa bergaul dengan warga di lingkungan rumahnya, pernah berkelahi dengan tetangga dan teman sekolahnya, berpacaran dengan sesama jenis serta pernah meminum alkohol secara tidak sengaja.

Sedangkan subjek $\mathrm{R}$ mengaku bahwa dirinya juga suka menolong, suka menegur tetangganya dan suka bersedekah, namun $\mathrm{R}$ hingga sekarang masih suka meminum minuman keras dengan alasan menghargai teman-temannya, suka mengucapkan kata-kata hinaan terhadap orang lain, bermesraan dengan sesama jenis, $\mathrm{R}$ juga sekarang mengaku bekerja sebagai penyanyi dangdut dimana dia mengenakan pakaian wanita yang sangat terbuka, memakai riasan wajah dan aksesoris seperti wanita yang sangat mencolok serta begoyang dengan semberono apabila sedang bernyanyi di atas panggung.

Berdasarkan dari dimensi-dimensi yang telah peneliti sebutkan, dapat di klasifikasikan pengikut agama berdasarkan dimensi-dimensi religiusitas menurut Paloutzian (Jalaluddin Rakhmat, 2004), yaitu :

1. Klasifikasi dimensi keyakinan dan dimensi pengetahuan agamanya yaitu: 
a. Iman berpengetahuan : ada iman dan ada pengetahuan

b. Iman buta : ada iman tapi tidak ada pengetahuan

c. Penolakan berpengetahuan : tidak ada iman tapi ada pengetahaun.

d. Penolakan buta : tidak ada iman dan tidak ada pengetahuan.

Dalam klasifikasi ini subjek $\mathrm{V}$ memiliki dimensi keyakinan yang kuat dan dimensi pengetahuan agama yang kurang, yang berarti $\mathrm{V}$ dapat diklasifikasikan dengan golongan yaituIman buta, dimana ada iman tapi tidak ada pengetahuan. Jadi subjek V mempercayai agamanya secara membuta dikarenakan mungkin hanya mengikuti orang-orang disekitarnya saja. Terbukti dengan pernyataan $\mathrm{V}$ yang mendapatkan pengetahuan agama yang terbatas karena hanya belajar pengetahuan agama di waktu kecil saja yaitu dari guru mengajinya dan guru MTsnya, namun R mengetahui beberapa dasar-dasar Islam mengenai kewajiban kewajibannya sebagai umat muslim.

Sedangkan subjek $\mathrm{R}$ memiliki dimensi keyakinan yang kuat dan dimensi pengetahuan agama yang cukup, yang berarti $\mathrm{V}$ dapat diklasifikasikan dengan golongan yaitu Iman berpengetahuan, yaitu dimana ada iman dan ada pengetahuan.Terbukti dengan $\mathrm{R}$ yang selalu mengikuti pengajian rutin di komunitasnya hingga sekarang, walaupun dirinya juga hanya mendapatkan pengetahuan agama lebih banyak dari gurunya di waktu MTs, dan tidak bisa mengaji dengan lancar, namun R setidaknya mengetahui dasar-dasar Islam.

2. Klasifikasian berdasarkan hubungan keyakinan dan pengamalan yaitu (Jalaluddin Rakhmat, 2004):

a. Mukmin konsisten : ada iman dan ada amal

b. Munafik : ada iman tapi tidak ada amal.

c. Agnostik moral : tidak ada iman tetapi beramal baik.

d. Non-mukmin konsisten : tidak ada iman dan tidak ada amal

Dalam klasifikasi ini, subjek $\mathrm{V}$ memiliki dimensi keyakinan sangat kuat dan dimensi pengamalan yang kurang, yang berarti subjek $\mathrm{V}$ dapat diklasifikasikan dengan golongan yaitu munafik, dimana ada iman tapi tidak ada amal. Dia tahu bahwa hukum berpacaran, apa lagi dengan sesama jenis dan minum-minuman itu haram namun tetap dilakukannya, dia juga mengetahui bahwa memiliki sifat pemarah dan pendendam itu sungguh tidak baik untuk di pelihara namun tetap tidak bisa mengubahnya, yang akhirnya menjerumuskannya keperkelahian. Dalam hal ibadah juga seperti itu, dia tahu bahwa sholat lima waktu dan sholat Jumat adalah hal yang diwajibkan padanya, namun dia tidak mengerjakannya.

Subjek R memiliki dimensi keyakinan yang sangat kuat dan dimensi pengamalan yang kurang, sama halnya dengan subjek $\mathrm{V}$, yang berarti subjek $\mathrm{R}$ dapat diklasifikasikan dengan golongan yaitu munafik, dimana ada iman tapi tidak ada amal. Dia tahu bahwa hukum berpacaran, apa lagi dengan sesama jenis dan minum-minuman itu haram namun tetap dilakukan olehnya bahkan hingga sekarang, dia juga sering menggunakan kata-kata hinaan dalam berbicara dengan orang lain. Baik V maupun $\mathrm{R}$ dalam hal beribadah, dirinya tahu bahwa sholat lima waktu dan sholat Jumat adalah hal yang diwajibkan padanya, namun dia tidak mengerjakannya. 


\section{Faktor-Faktor yang Mempengaruhi Reliugisitas pada Waria berusia Remaja}

Menurut H. Thouless (Raharjo, 2012), terdapat beberapa fator yang mempengaruhi religiusitas, yaitu:

Pengaruh sosial

Dalam perkembangan rasa agama terdiri dari berbagai pengaruh terhadap keyakinan dan perilaku agama, pendidikan pada masa kanak-kanak dari orang tua maupun lembaga pendidikan, berbagai pendapat dan sikap orang-orang disekitar, dan tekanan-tekanan lingkungan sosial untuk menyesuaikan diri dengan berbagai pendapat yang disepakati bersama (Raharjo, 2012).

\section{Berbagai pengalaman}

Faktor berbagai pengalaman juga merupakan faktor yang memberikan pengaruh terhadap perkembangan rasa agama, faktor pengalaman ada tiga (Okdinata, 2009) :

a. Pengalaman dunia nyata (faktor alami). Pengalaman ini memberikan pengaruh pada perkembangan sikap keagamaan mengenai manfaat, keharmonisan dan keindahan.

b. Konflik moral (faktor moral). Pengalaman ini lebih bersifat internal pada individu itu sendiri yakni suatu pengalaman mengenai konflik antara beberapa kecenderungan perilakunya sendiri dengan sistem tatanan hukum moral yang ada atau hal yang bertentangan dengan hukum moral ini secara psikologik muncul dalam diri individu yang disebut dengan konflik moral.

c. Pengalaman emosional keagamaan (faktor afektif). Setiap pemeluk agama memiliki pengalaman emosional dalam kadar tertentu yang berkaitan dengan keyakinan agamanya, tapi setiap individu mempunyai pengalaman-pengalaman emosional keagamaan yang berbeda

Kebutuhan

Dorongan-dorongan kebutuhan hidup yang tidak sepenuhnya terpenuhi, terutama kebutuhan terhadap (Raharjo, 2012) :

a. Keamanan atau keselamatan : Berhubungan dengan perlindungan, keteraturan, stabilitas, situasi yang bisa diperkirakan, bebas dari rasa takut dan cemas.

b. Cinta kasih : kebutuhan ini yaitu keinginan untuk memiliki dan dimiliki, memberi dan menerima kasih sayang, kehangatan, persahabatan dan kekeluargaan.

c. Harga diri : perasaan dihargai oleh orang lain serta pengakuan dari orang lain

d. Ancaman kematian

Proses pemikiran atau intelektual

Manusia sebagai mahkluk yang dapat berfikir tentu tidak bisa menerima suatu kebenaran dan kesalahan begitu saja, semuanya dicerna melalui nalar, hal ini juga memberi pengaruh dalam perkembangan rasa agama masa kanak-kanak ke remaja. 
Diantara empat faktor religiusitas tersebut, berdasarkan dari hasil wawancara dan observasi yang diperoleh oleh peneliti, terhadap subjek $\mathrm{V}$ dan subjek $\mathrm{R}$, faktor utama yang mempengaruhi religiusitas kedua subjek yaitu faktor pengaruh sosial serta faktor kebutuhan sebagai faktor pendamping. Dimana pengaruh sosial yang dimaksud meliputi dari keyakinannya, rasa beragama yang dimilikinya, berbagai pendapat dan sikap orang-orang disekitarnya, terutama pendidikan pada masa kanak-kanak dari orang tua maupun lembaga pendidikan yang diperolehnya. Hasil dari pengetahuan agama yang di dapatkan oleh kedua subjek menunjukan bahwa peran orangtua mereka kurang berperan aktif dalam pengembangan pengetahuan agama, dimana membuat mereka termasuk memiliki penegetahuan agama yang kurang. Seharusnya orangtualah yang memberikan pengetahuan agama kepada anaknya sejak dini secara intens, apabila hal itu terjadi maka terciptalah pengetahuan agama yang bagus terhadap kedua subjek, yang mana hal ini sesuai dengan pernyatatan Crapss, yaitu bimbingan agama yang diberikan orangtua sejak dini akan memberikan pondasi bagi perkembangan religiusitas berikutnya. Dari lingkungan yang penuh kasih sayang yang diciptakan oleh orangtua, lahirlah pengalaman keagamaan yang mendalam selama masa kanak-kanak (Afiatin, 1998).

Dalam faktor kebutuhan yang dimaksud dalam peneliti yaitu ada dorongan atau kebutuhan dari dirinya untuk memililiki rasa keamanan dan keselamatan dari Allah SWT yang berhubungan dengan perlindungan, situasi yang bisa diperkirakan, bebas dari rasa takut dan cemas. Hasil penelitian ini sesuai dengan pendapat Powel, yang juga menyatakan agama dapat memberikan kemantapan pada waktu remaja mengalami kebimbangan, agama bagi waria berusia remaja dianggap sebagai kebutuhan yang bersifat personal dan penuh makna, tidak hanya ketika mendapatkan kesulitan namun juga dianggap sebuah sumber pegangan hidup, sumber kekuatan, perlindungan dan rasa aman untuk dirinya (Ghufron \& Risnawita, 2010).

\section{Kesimpulan}

Pada dimensi keyakinan, V memiliki keyakinan yang sangat kuat terhadap rukun iman. Pada dimensi peribadatan atau praktik agama $\mathrm{V}$ masih tidak dapat melakukan kewajiban ibadahnya dengan sempurna, yang membuat $\mathrm{V}$ kurang bagus dalammelakukan peribadatan atau praktik agama. Pada dimensi penghayatan, $\mathrm{V}$ memiliki penghayatan yang cukup bagus dalam beragama. Pada dimensi pengetahuan agama, $\mathrm{V}$ memiliki pengetahuan agama yang kurang. Dimensi terakhir yaitu dimensi pengamalan, $\mathrm{V}$ memiliki pengamalan yang kurang bagus.

Subjek R juga memiliki keyakinan yang sangat kuat terhadap semua rukun iman. Pada dimensi peribadatan atau praktik agama $\mathrm{R}$ memiliki peribadatan atau praktikagama yang kurang, karena $\mathrm{R}$ sangat sering meninggalkan kewajiban beribadah. Pada dimensi penghayatan, $\mathrm{R}$ memiliki penghayatan agama yang sangat bagus. Pada dimensi pengetahuan agama, $\mathrm{R}$ memiliki pegetahuan mengenai dasar-dasar agama yang cukup bagus. Pada dimensi terakhir yaitu dimensi pengamalan, R memiliki pengamalan yang kurang bagus.

Berdasarkan dari hasil wawancara dan observasi yang diperoleh oleh peneliti, faktor utama yang mempengaruhi religiusitas kedua subjek yaitu faktor pengaruh sosial sebagi faktor 
utama dan faktor kebutuhan yang menjadi faktor pendamping. Dimana pengaruh sosial yang dimaksud meliputi dari keyakinannya, rasa beragama yang dimilikinya, pendidikan pada masa kanak-kanak dari orang tua maupun lembaga pendidikan yang diperolehnya, berbagai pendapat dan sikap orang-orang disekitarnya. Dalam faktor kebutuhan yang dimaksud yaitu ada dorongan atau kebutuhan dari dirinya untuk memililiki rasa keamanan dan keselamatan dari Allah SWT yang berhubungan dengan perlindungan, situasi yang bisa diperkirakan, bebas dari rasa takut dan cemas.

Saran

Penelitian ini merekomendasikan adanya pelatihan dibidang keagamaan agar para waria dapat mengisi kesehariannya dengan kegiatan yang positif, seperti pelatihan membaca Al-Qur'an, Pelatihan tata cara sholat fardhu, pelatihan sholat atau memandikan jenazah dan lain-lain.

\section{Referensi}

Afiatin, T. (1998). Religiusitas Remaja: Studi Kasus Tentang Kehidupan Beragama di Daerah Istimewa Yogyakarta. Jurnal Psikologi.

Ancok, D., \& Nashori, F. (2008). Psikologi Islami. Yogyakarta: Pustaka Pelajar.

Dewi Muthi'ah. (2007). Konsep Diri dan Latar Belakang Kehidupan Waria (Studi Kasus Terhadap Waria di Kota Semarang Tahun 2007) (Skripsi). Universitas Negeri Semarang, Semarang.

Fahmi, I., \& Kusdiyati, S. (2015). Observasi Psikologi. Bandung: PT Remaja Rosdakarya.

Faidah, M., \& Abdullah, H. (2014). Religiusitas dan Konsep Diri Kaum Waria. Jurnal Studi Gender Indonesia, 4(1), 1-14.

Ghufron, M. N., \& Risnawita, R. (2010). Teori-teori psikologi. Yogyakarta: Ar-Ruzz Media.

Husaini, M. (2016). Pengaruh Religiusitas dan Kondisi Psikologis Terhadap Perilaku Kerja Karyawan Toko Buku Fajar Agung Bandar Lampung (Skripsi). Universitas Lampung, Lampung.

Jalaluddin Rakhmat. (2004). Psikologi Agama: Sebuah Pengantar. Bandung: Mizan.

Khairunnisa, D., \& Indrawati, E. S. (2017). Sebuah Studi Fenomenologi Tentang Religiusitas pada Santri Pondok Pesantren Waria Al-Fatah Yogyakarta. Jurnal Empati, 6, 7.

Medya, R., \& C Kristiaji, W. (2005). Psikologi Abnorman Jilid 2. Yogyakarta: PT. Gelora Aksara Pratama.

Muiz, A. (2015). Benang Kusut Fiqh Waria (Analisis Kritis Terhadap Polemik Identitas Waria Dalam Islam). AT-TURAS: Jurnal Studi Keislaman, 2(1), 74-90.

Okdinata. (2009). Religiusitas Kaum Homoseks (Studi Kasus Dinamika Psikologis Keberagamaan Gay Muslim di Yogyakarta) (Skripsi). Universitas Islam Negeri Kalijaga, Yogyakarta.

Raharjo. (2012). Ilmu Jiwa Agama. Semarang: Pustaka Rizki Putra.

Rahmadi. (2011). Pengantar Metodelogi Penelitan. Banjarmasin: Antasari Press.

Rizky Setiawan. (2014). Dinamika Religiusitas Siswa Muslim di Sekolah Non Islam (Studi Kasus Tiga Siswa Muslim di SMA Santo Thomas Yogyakarta) (Skripsi). Universitas Islam Negeri Kalijaga, Yogyakarta.

Ruhghea, S., Mirza, \& Rachmatan, R. (2014). Studi Kualitatif Kepuasan Hidup Pria Transgender (Waria) di Banda Aceh. Jurnal Psikologi UNDIP, 13(1), 11-20. 
Safri, A. N. (2014a). Pesantren Waria Senin-Kamis Al-Fatah Yogyakarta: Sebuah Media Eksistensi Ekspresi Keberagamaan Waria. ESENSIA: Jurnal Ilmu-Ilmu Ushuluddin, 15(2).

Safri, A. N. (2014b). Pesantren Waria Senin-Kamis Al-Fatah Yogyakarta: Sebuah Media Eksistensi Ekspresi Keberagamaan Waria. ESENSIA: Jurnal Ilmu-Ilmu Ushuluddin, 15(2), 251.

Sarwono, S. W. (2012). Psikologi Remaja. Jakarta: Raja Grafindo Persada.

Satriani. (2011). Hubungan Tingkat Religiusitas Dengan Kecemasan Moral Mahasiswa Ushuluddin UIN Suska Riau (Skripsi). Universitas Islam Negeri Sultas Syarif Kasim Riau, Riau.

Sudarman, \& Hakim, L. (2015). Eksklusifitas Keberagamaan Waria Pekerja Salon Kota Padang. Kafa `ah: Journal of Gender Studies, 5(2), 147.

\begin{tabular}{|l|l|l|l|l|}
\hline Submit & Review & Revisi & Diterima & Publis \\
\hline 08-07-2020 & 05-10-2020 sd 24-10-2020 & $11-04-2021$ & $12-04-2021$ & $12-06-2021$ \\
\hline
\end{tabular}

Rahmawati, Hadariansyah, Imadduddin

Universitas Islam Negeri (UIN) Antasari Banjarmasin

Email : amawati06@gmail.com, hadariansyah@gmail.com, imadduddin@uin-antasari.ac.id 